\title{
Penerapan Metode Diskusi Terbimbing untuk Meningkatkan Kemampuan Guru dalam Pembuatan RPP di SMKN 3 Gowa
}

\author{
H. Karnedy Bolong \\ Kepala UPT SMKN 3 Gowa - Provinsi Sulawesi Selatan \\ *Corresponding Author. Email: karnedybolong@ gmail.com
}

\begin{abstract}
The purpose of this study was to improve the ability of teachers in making lesson plans through guided discussions at SMKN 3 Gowa. The research used is school action research which is carried out in 2 . This research instrument uses tests and non-tests. The data analysis technique used was descriptive which was carried out through three stages, namely: data reduction, data exposure, and inference. The results of this study indicate that the data in the first cycle with an average value of 59.7 with completeness of $43.3 \%$ and the ability of teachers to use lesson plans by $50 \%$ where these results have not reached the target set, then the action is taken in Cycle II by doing improvement of learning and lesson plans, so that learning outcomes increase to $72.0 \%$. So it can be concluded that the guided discussion method can improve the ability of teachers in making lesson plans at SMKN 3 Gowa.
\end{abstract}

\begin{abstract}
Abstrak: Tujuan penelitian ini adalah untuk meningkatkan kemampuan guru dalam pembuatan RPP melalui diskusi terbimbing di SMKN 3 Gowa. Penelitian yang digunakan adalah penelitan tindakan sekolah yang dilakuakan dalam 2 . Instrument penelitian ini menggunakan tes dan non-tes. Teknik analisis data menggunakan deskriptif yang dilakukan melalui tiga tahap yaitu: reduksi data, paparan data, dan penyimpulan. Hasil penelitian ini menunjukkan bahwa data siklus I dengan nilai rata-rata sebesar 59,7 dengan ketuntasan sebesar 43,3\% dan kemampuan guru dalam penggunaan RPP sebesar 50\% dimana hasil ini belum mencapai target yang ditetapkan, maka dilakukan tindakan pada Siklus II dengan dilakukan perbaikan pembelajaran dan RPP, sehingga hasil pembelajaran meningkat menjadi $72,0 \%$. Sehingga dapat disimpulkan bahwa metode diskusi terbimbing dapat meningkatkan kemampuan guru dalam pembuatan RPP di SMKN 3 Gowa.
\end{abstract}

\section{Article History}

Received: 03-08-2021

Revised: $10-09-2021$

Accepted: 20-09-2021

Published: 05-10-2021

\section{Key Words: \\ Ability of Teachers, \\ Lesson Plans, Guided \\ Discussions.}

\section{Sejarah Artikel \\ Diterima: 03-08-2021 \\ Direvisi: $10-09-2021$ \\ Disetujui: 20-09-2021 \\ Diterbitkan: 05-10-2021}

\section{Kata Kunci:}

Kemampuan Guru, RPP, Diskusi Terbimbing.

How to Cite: Bolong, H. (2021). Penerapan Metode Diskusi Terbimbing untuk Meningkatkan Kemampuan Guru dalam Pembuatan RPP di SMKN 3 Gowa. Jurnal Paedagogy, 8(4), 534-539. doi:https://doi.org/10.33394/jp.v8i4.4103

https://doi.org/10.33394/jp.v8i4.4103

This is an open-access article under the CC-BY-SA License.

\section{Pendahuluan}

Proses pendidikan merupakan proses sosial yang selalu melibatkan beberapa individu dengan berlatar belakang pribadi dan cara belajar yang berbeda akan tetapi mempunyai tujuan yang sama. Proses tersebut diupayakan agar materi yang disampaikan dapat menyenangkan dan menarik peserta didik. Dalam proses tersebut salah satu hal yang perlu mendapat perhatian adalah penggunaan metode pembelajaran agar dapat diperoleh kualitas pembelajaran yang optimal (Tilaar, 2008; Syah, 2004).

Dalam proses belajar mengajar di tingkat sekolah menengah kejuruan, seringkali guru diharapkan pada masalah metode mengajar yang akan diterapkan kepada siswa (Kamaruddin, 2021). Pemilihan metode belajar menjadi sangat penting karena banyaknya metode proses belajar mengajar yang ada, tidak semua sesuai dan dapat diterapkan dalam proses belajarmengajar di tingkat sekolah menengah kejuruan. 
Proses pembelajaran merupakan suatu sistem yang terdiri dari unsur-unsur yang saling berinteraksi antara lain guru, peserta didik, diskusi terbimbing, dan kurikulum (Sagala, 2006). Unsur-unsur tersebut diharapkan saling berkaitan. Bagaimana sikap dan kepribadian guru, tinggi rendahnya pengetahuan yang dimiliki guru, dan bagaimanana cara guru itu mengajarkan kepada siswanya, turut menentukan hasil belajar yang dapat dicapai siswa. Pendidik menyampaikan materi pelajaran sedangkan peserta didik mengikuti dan mendengarkan apa yang disampaikan oleh pendidik. Kegiatan belajar mengajar yang dilakukan individu bertujuan untuk dapat menghasilkan perubahan yang mana pembahasanpembahasan yang dihasilkan dari proses belajar mempunyai bentuk yang beraneka ragam, hal yang demikian itu dikarenakan bahwa belajar adalah suatu proses aktif.

Dalam Undang-undang Republik Indoresia Nomor 14 Tahun 2005 tentang Guru dan Dosen pasal 1 ayat 1 diungkapkan bahwa guru adalah pendidik professional dengan tugas utama yaitu mendidik, mengajar, membimbing, mengarahkan, melatih, menilai, dan mengevaluasi peserta didik pada pendidikan anak usia dini jalur pendidikan formal, pendidikan dasar, dan pendidikan menengah. Dalam kaitannya dengan peningkatan profesionalisme seorang guru memerlukan diskusi terbimbing dalam mengembangkan pembelajaran. Dalam proses pembelajaran, diskusi terbimbing selalu mengacu pada kegiatan memperbaiki proses pembelajaran seperti meningkatkan profesinya, kemampuan berkomunikasi, dan kemampuan kontekstual karena seorang guru harus selalu meningkatkan kemampuan profesionalnya, pengetahuan, sikap, dan keterampilannya secara terus menerus sesuai dengan perkembangan ilmu pengetahuan dan teknologi (Mulyasa, 2004; Wahyuni, 2021).

Oleh karena itu, diperlukan suatu diskusi terbimbing untuk memperbaiki metode pembelajaran, dalam berkomunikasi, dan pengembangan diri. Sehingga diharapkan kemampuan guru di SMKN 3 Gowa dapat ditingkatkan, guru melaksanakan proses pembelajaran dengan baik, dan siswa mengerti materi yang di sampaikan dan memiliki motivasi untuk mengikuti pembelajaran. Adapun tujuan penelitian ini adalah untuk meningkatkan kemampuan guru dalam pembuatan RPP melalui diskusi terbimbing di SMKN 3 Gowa.

\section{Metode Penelitian}

Metode penelitian yang digunakan adalah penelitian tindakan sekolah (PTS). Model yang digunakan dalam PTS ini model proses siklus (putaran/spiral) yang mengacu pada model dari Kemmis dan Mc. Taggart (Arikunto, 2008; Sukardi, 2005; Sugiyono, 2009). Model dari putaran ke putaran atau siklus ke siklus dengan target peningkatan kemampuan dengan 2 siklus dan setiap siklus terbagi menjadi 2 kali pertemuan Setiap pertemuan dilaksanakan pembelajaran dengan alokasi 2 jam pelajaran x 40 menit. Subyek penelitian ini adalah guru-guru di SMKN 3 Gowa Provinsi Sulawesi Selatan. Instrumen penelitian ini menggunakan tes dan non-tes. Selain itu, teknik pengumpulan data juga dilakukan melalui observasi dan catatan lapangan, Observasi digunakan untuk mengetahui kekurangan atau kesulitan dengan rencana pembelajaran yang digunakan pada proses pembelajaran untuk mencatat proses pembelajaran yang berlangsung untuk mencatat pembelajaran.

Teknik analisis data penelitian ini menggunakan analisis deskriptif yang dilakukan melalu tiga tahapan yaitu: reduksi data, paparan data, dan penyimpulan. Reduksi data adalah proses penyederhanaan data yang diperoleh melalui pengamatan dengan cara memilih data yang sesuai dengan kebutuhan penelitan. Dari pemilihan data tersebut, kemudian dipaparkan 
menjadi paparan lebih sederhana, sehingga akhirnya dapat ditarik kesimpulan dalam bentuk pernyataan kalimat yang singkat dan padat, tetapi mengandung pengertian yang luas.

\section{Hasil Penelitian dan Pembahasan Deskripsi Siklus I}

Setelah dilakukan tindakan, selanjutnya melakukan analisis hasil, baik proses maupun tes tertulis, untuk melihat sejauh mana tingkat keaktifan dan hasil belajar siswa. Adapun peningkatan hasil belajar siswa setelah dilakukan tindakan pada siklus I ada peningkatan dibandingkan pada kondisi awal. Hasil pengamatan terhadap kegiatan siswa selama proses belajar-mengajar, cukup baik. Siswa tampak mulai aktif dan mau menyampaikan argumentasi dalam berdiskusi.

Pengamatan terhadap materi pembelajaran oleh guru diperoleh jumlah skor pemantauan terhadap aktivasi guru dan jumlah pertanyaan 10 diperoleh skor 25 sehingga persentase sebesar 50,0\% .Dari aspek pengamatan yang dilakukan dapat di hitung persentase kemampuan dalam pengunaan RPP dengan rata-rata presentase sebesar 50,0\%. Dari penelitian tersebut diperoleh nilai rata-rata hasil belajar siawa sebesar 59,7 dengan persentase ketuntasan 43,3\% dan meningkat dibandingkan dengan hasil pretes dengan nilai rata rata hasil belajar siswa sebesar 50,0 dengan persentase ketuntasan 23,3\%.

Dengan demikian kemampuan guru dalam penyusunan RPP baru mencapai 50,0\%, sedangkan target kemampuan guru dalam membuat RPP untuk mata pelajaran adalah ratarata sebesar $70 \%$ dan target ketuntasan hasil belajar adalah $80,0 \%$. Untuk itu perlu diadakan Siklus II untuk memperbaiki yang kurang dan meningkatkan yang sudah baik dengan melakukan diskusi terbimbing dalam pembelajaran.

Setelah dilakukan pembelajaran yang langsung dipantau dan telah diungkapkan hasilnya di atas, maka selanjutnya dilakukan refleksi. Proses refleksi ini merenungkan kembali kegiatan pembelajaran yang telah dilakukan. Temuan itu diantaranya adalah penyampaian tujuan pembelajaran belum dilakukan dengan benar dan perlu alat peraga bagi siswa secara langsung dirasakan oleh siswa, agar siswa berminat untuk mengikuti pelajaran. Pembelajaran yang dilakukan oleh guru belum sepenuhnya dilakukan dengan benar sehingga sebagian besar siswa belum mengetahui makna pembelajaran yang dilukukan. Oleh karena itu peningkatan kemampuan guru dalam merancang pembelajaran melalui diskusi terbimbing agar pembelajaran dapat menggunakan alat peraga agar penyampaian materi pelajaran dapat dipahami dengan baik oleh siswa.

Guru perlu memberi penguatan agar siswa yang lain tidak takut mencoba mengidentifikasikan materi pembelajaran di sekitar rumah dan sekolah. Penguatan ini dapat berupa penghargaan atau wujud nyata seperti memberikan pujian karena siswa mampu menryelesaikan soal dengan benar. Dalam proses pembelajaran, perhatian guru belum menyeluruh ke semua kelompok belajar, sehingga siswapun belum dapat berdiskusi sccara maksimal karena siswa yang pandai masih mendominasi dalam proses diskusi. Guru belum maksimal menyampaikan tentang bagaimana mencapai tujuan yang jelas agar siswa dapat belajar dengan sungguh-sungguh. Guru belum sepenuhnya membantu siswa menemukan proses rumus melalui penggunaan alat peraga sehingga siswa yang pandai saja yang mampu memanfaatkan alat peraga dengan benar dan masih banyak siswa yang belum mampu mengemukakan gagasan tersebut.

\section{Deskripsi Siklus II}

Setelah dilakukan tindakan, selanjutnya melakukan analisis hasil, baik proses maupun tes tertulis, untuk melihat sejauh mana tingkat keaktifan dan hasil belajar siswa. Adapun 
peningkatan pembelajaran setelah dilakukan tindakan pada siklus II ada peningkatan kemampuan guru dalam pembuatan RPP dibandingkan pada kondisi Siklus I. hasil pengamatan terhadap kegiatan siswa selama proses belajar-mengajar, sangat baik. Siswa sudah aktif dan mau menyampaikan argumentasi dalam berdiskusi.

Pengamatan terhadap aktivitas pembelajaran dengan memanfaatkan RPP oleh guru diperoleh jumlah skor pemantauan terhadap aktivitas guru dari jumlah pertanyaan 35 sehingga diperoleh persentase sebesar $72 \%$. Dari aspek pengamatan yang dilakukan dapat dihitung persentase pemanfaatan alat peraga dengan rata-rata persentase sebesar $72,0 \%$

Sedangkan hasil kemampuan guru dalam pembuatan RPP diperoleh nilai rata rata hasil belajar siswa sebesar 77,3 dengan persentase ketuntasan 83,3\%.

Dengan demikian kemampuan guru dalam pembuatan dan menggunakan RPP sudah mencapai $72,0 \%$, sedangkan target kemampuan guru dalam pembuatan RPP adalah rata rata sebesar 70,0\%. Dengan demikian sudah mencapai target yang diinginkan dalam hal kemampuan guru dalam pembuatan RPP dan hasil pembelajaran sudah memenuhi kriteria ketuntasan yang diinginkan yaitu $80 \%$.

Berdasarkan hasil evaluasi dan observasi Siklus II, terjadi peningkatan kemampuan guru dalam pembuatan RPP sudah mencapai target yang diinginkan, begitu juga halnya dengan hasil belajar siswa dalam memahami materi pembelajaran sudah meningkat.

Perbaikan RPP yang dilakukan dalam pembelajaran melalui diskusi terbimbing sebagai metode pembelajaran dalam penelitian ini ternyata dapat membantu dalam peningkatan hasil belajar siswa SMKN 3 Gowa selama dalam pembelajaran siswa sudah aktif dalam kegiatan diskusi, keberanian memberikan argumentasi dalam mengidentifikasikan tentang pembelajaran sehingga terjadi proses pembelajaran yang memberikan dampak positif terhadap hasil belajar siswa dan kemampuan guru dalam pembelajaran.

\section{Analisis Hasil Penelitian}

Setelah melakukan evaluasi baik proses maupun hasil belajar, dapat dilakukan analisis data dengan analisisi proses dan analisis hasil.

\section{Kondisi Awal}

Pada kondisi awal, keaktifan, keberanian merumuskan dan ketekunan siswa selama pembelajaran masih kurang, siswa terlihat pasif. Ketika dilakukan tes awal atau pretes nilai rata-rata kelas 50,0 dengan presentase ketuntasan sebesar 43,3\% masih kurang dari target yaitu sebesar 75 .

\section{Siklus I}

Pada siklus I, keaktifan, pemahaman, keberanian bertanya, dan ketekunan siswa selama pembelajaran mengalami peningkatan, keterampilan guru dalam menggunakan alat peraga sudah mulai baik, tetapi masih belum memberikan hasil belajar sesuai dengan target hasil belajar yang diharapkan. Hal ini dapat dilihat dari hasil belajar rata-rata hanya sebesar 59,7.

\section{Siklus II}

Pada siklus II, keaktifan, pemahaman, keberanian bertanya, dan ketekunan siswa menunjukkan perubahan yang signifikan, keterampilan guru dalam menggunakan alat peraga sudah baik, hal ini dapat dilihat dari hasil belajar yang sesuai dengan target hasil belajar ratarata dan sudah melebihi target yang ditentukan yaitu sebesar 77,3.

\section{Pembahasan}

Dari hasil analisis data nilai rata-rata kelas 69,30, dapat disimpulkan bahwa ada perbedaan antara hasil belajar siswa sebelum tindakan dan setelah tindakan pada Siklus 1 . berdasarkan hasil evaluasi pada Siklus I, namun perubahan tersebut belumlah mencapai target 
yang diinginkan. Dari hasil evaluasi terlihat pada Siklus I untuk aspek proses dalam pembelajaran masih kurang memuaskan. Keaktifan dan keberanian mengidentifikasikan masalah pembelajaran masih belum terlihat. Kemampuan guru dalam pembuatan RPP masih belum memberikan hasil baik, hal ini disebabkan karena pada Siklus I pelaksanaan tindakan dilakukan dengan penggunaan alat peraga yang belum dipahami dengan baik oleh siswa, sehingga penggunaan alat peraga dalam pembelajaran belum optimal hasil yang diperoleh.

Berdasarkan kondisi yang diperoleh dalam tindakan ini, maka pembelajaran dilanjutkan ke Siklus II. Pada Siklus II tindakan yang dilakukan setelah dilakukan perbaikan RPP dan memberikan arahan tentang materi pembelajaran dengan benar agar hasil pembelajaran lebih baik lagi. Dari hasil analisis data Siklus II nilai rata rata hasil belajar meningkat menjadi 77,07, begitu juga dengan kemampuan guru dalam penggunaan RPP meningkatkan menjadi $72,02 \%$. Hasil ini dapat disimpulkan bahwa terdapat peningkatan kemampuan guru pada Siklus II baik aspek proses maupun hasil belajar siswa. Selama pembelajaran siswa aktif dan kreatif dalam mengidentifikasi permasalahan tentang pelajaran dan cara penanggulangannya dengan baik terhadap apa yang diinginkan dalam pembelajaran. Adapun penelitian ini relevan dengan hasil penelitian dari Salim (2017), Jamilan (2017), dan Yatmini (2016) yang menjelaskan bahwa kemampuan guru dalam membuat RPP memiliki dampak terhadap keaktifan dan hasil belajar siswa.

\section{Kesimpulan}

Kesimpulan yang diperoleh dari hasil penelitian ini adalah data siklus I dengan nilai rata-rata sebesar 59,7 dengan ketuntasan sebesar 43,3\% dan kemampuan guru dalam penggunaan RPP sebesar 50\% dimana hasil ini belum mencapai target yang ditetapkan, maka dilakukan tindakan pada Siklus II dengan dilakukan perbaikan pembelajaran dan RPP, sehingga hasil pembelajaran meningkat menjadi 72,0\%. Sehingga dapat disimpulkan bahwa metode diskusi terbimbing dapat meningkatkan kemampuan guru dalam pembuatan RPP di SMKN 3 Gowa.

\section{Saran}

Adapun saran yang disampaikan berdasarkan hasil penelitian ini yakni bagi dinas pendidikan agar hasil penelitian ini dapat menjadi masukan dalam memberikan rekomendasi dalam upaya sebagai bekal kesiapan guru menyusun RPP yang optimal.

\section{Daftar Pustaka}

Arikunto, S. (2008). Prosedur Penelitian Suatu Pendekatan Praktik. Jakarta: Rineka Karya.

Jamilan, J. (2017). Melaksanakan Bimbingan Berbasis KKG sebagai Upaya Meningkatkan Kompetensi Guru Kelas dalam Penyusunan RPP Berkarakter di SDN 46 Mataram. Jurnal Kependidikan: Jurnal Hasil Penelitian dan Kajian Kepustakaan di Bidang Pendidikan, Pengajaran dan Pembelajaran, 3(1). doi:https://doi.org/10.33394/jk.v3i1.470

Kamaruddin, H. (2021). Upaya Meningkatkan Kompetensi Guru SMK Negeri 4 Gowa dalam Melaksanakan Proses Pembelajaran di Kelas Melalui Program Supervisi. Jurnal Paedagogy, 8(3), 414-421. doi:https://doi.org/10.33394/jp.v8i3.3894

Mulyasa, E. (2004). Menjadi Kepala Sekolah Profesional. Bandung: Remaja

Sagala, Syaiful. (2006). Konsep dan Makna Pembelajaran; Untuk Membantu Memecahkan Problematika Belajar dan Mengajar, Bandung: Penerbit Alfabeta

Salim, A. (2017). Mengoptimalkan Pendampingan Berbasis KKG dalam Upaya Meningkatkan Kompetensi Guru Kelas SD 29 Mataram dalam Penyusunan 
RPP. Jurnal Kependidikan: Jurnal Hasil Penelitian dan Kajian Kepustakaan di Bidang Pendidikan, Pengajaran dan Pembelajaran, 3(1). doi:https://doi.org/10.33394/jk.v3i1.392

Sugiyono. (2009). Statistika Untuk Penelitian, Bandung: Alfabeta

Sukardi. (2005). Metodologi Penelitian Pendidikan: Kompetensi dan Praktiknya, Jakarta: Bumi Aksara.

Syah, Muhibin. (2004). Psikologi Pendidikan Dengan Pendekatan Baru, Bandung: Penerbit PT. Remaja Rosdakarya.

Tilaar, H. AR. (2008). Manajemen Pendidikan Nasional. Bandung: Remaja Rosdakarya

Wahyuni, T. (2021). Supervisi Klinis oleh Kepala Sekolah guna Meningkatkan Kompetensi Guru dalam Mengelola Administrasi Kelas di SD Negeri 42 Ampenan. Jurnal Paedagogy, 8(2), 264-270. doi:https://doi.org/10.33394/jp.v8i2.3561

Yatmini, Y. (2016). Meningkatkan Kompetensi Guru dalam Penyusunan RPP yang Baik dan Benar Melalui Pendampingan Berbasis KKG di SDN Model Mataram. Jurnal Kependidikan: Jurnal Hasil Penelitian dan Kajian Kepustakaan di Bidang Pendidikan, Pengajaran dan Pembelajaran, 2(2). doi:https://doi.org/10.33394/jk.v2i2.462 